\title{
HIGHLIGHTS
}

HIGHLIGHT ADVISORS

\section{UELI AEB}

UNIVERSITY OF BASEL, SWITZERLAND

TOM L. BLUNDELL

UNIVERSITY OF CAMBRIDGE, UK

JOAN S. BRUGGE

HARVARD MEDICAL SCHOOL, BOSTON, MA, USA

PASCALE COSSART

INSTITUT PASTEUR, PARIS, FRANCE

\section{PAMELA GANNON}

CELL AND MOLECULAR

BIOLOGY ONLINE

\section{SUSAN M. GASSER}

UNIVERSITY OF GENEVA, SWITZERLAND

\section{JEAN GRUENBERG}

UNIVERSITY OF GENEVA, SWITZERLAND

\section{ULRICH HARTL}

MAX-PLANCK-INSTITUTE, MARTINSRIED, GERMANY

\section{STEPHEN P. JACKSON}

WELLCOME/CRC INSTITUTE, CAMBRIDGE, UK

\section{WALTER NEUPERT}

MUNICH UNIVERSITY, GERMANY

\section{TONY PAWSON}

SAMUEL LUNENFELD RESEARCH INSTITUTE, TORONTO, CANADA

\section{NORBERT PERRIMON}

HARVARD MEDICAL SCHOOL, BOSTON, MA, USA

\section{THOMAS D. POLLARD}

YALE UNIVERSITY, NEW HAVEN, CT, USA

\section{JOHN C. REED}

THE BURNHAM INSTITUTE, LA JOLLA, CA, USA

\section{ANNE RIDLEY}

LUDWIG INSTITUTE FOR CANCER RESEARCH, LONDON, UK

\section{KAREN VOUSDEN}

BEATSON INSTITUTE FOR CANCER RESEARCH, GLASGOW, UK

\section{PLANT DEVELOPMENT}

\section{Pinning down organ formation}

Plants depend mainly on postembryonic organ development to establish their adult form. And because plants are immobile, the ability to change their development in response to external cues is essential for survival.

Differences in the morphological and developmental features of rootand shoot-derived organs had indicated that there should be at least two different regulatory mechanisms for postembryonic organ development. But now, in Cell, Benková et al. show that there is a common mechanism for the formation of all plant organs.

The plant hormone auxin, which is known to have numerous roles in plant development, including organ initiation and positioning, is actively and directionally transported from its site of synthesis to all target tissues. The PIN family of auxin efflux regulators are the most well-characterized auxin transport proteins, and the relocation of PIN3 in response to gravity stimulation has been shown to redirect auxin fluxes during development. So, these authors wanted to know if PIN relocation and auxin redistribution was a common mechanism underlying organ formation.

Benková et al. first established that there is a dynamic auxin gradient that is mediated by auxin transport in Arabidopsis thaliana root-derived organ development. And the finding that at least six PIN genes are expressed in these developing organs provided a molecular basis for the auxin redistribution. Using pin mutants and transgenic plants overexpressing PIN1 in all cells, the authors confirmed that differentially expressed PIN proteins establish the auxin gradient (they also have distinct roles in the initiation and development of root primordia).

When exogenous auxin was added to single pin mutants, to trigger organogenesis, only mild defects in root-derived organ formation were seen, which indicated that there was functional redundancy of the PIN proteins. Indeed, much stronger defects in root-derived organ development were seen for multiple pin mutants, which also illustrates the importance of the auxin efflux. Benková et al. then showed that coordinated rearrangement of PIN1 localization occurs during root-derived organ development and that this relocation correlates with auxin gradients and correct primordium development.

The authors then looked to see if the same PIN-dependent auxin efflux and gradient operates in the formation of aerial organs - and it does. One difference was in the flow of auxin in developing shootderived organs, which was opposite to that seen in root-derived organs (described as 'reverse-fountain' and 'fountain', respectively). And in shoot-derived organs, PIN1 alone seems to have a dominant role in both organogenesis and local auxin distribution.

Despite these differences, PINdependent, local auxin gradients are a common module for organogenesis in Arabidopsis. And, taking evolutionary relationships into account, the authors speculate that this “...auxin transport-dependent mechanism ... also operates in organ formation in other higher plants".

Natalie Wilson

(D) References and links ORIGINAL RESEARCH PAPER Benková, E. et al. Local, efflux-dependent auxin gradients as a common module for plant organ formation. Cell 115, 591-602 (2003)

WEB SITE

Jiři Friml's laboratory:

http://www.uni-tuebingen.de/uni/bce/friml/ 